\title{
A vasopressin analogue in treatment of diabetes insipidus
}

\author{
RIVKA KAULI and ZVI LARON \\ From the Institute of Paediatric and Adolescent Endocrinology, Beilinson Medical Center, Petach Tikva; and the \\ Sackler School of Medicine, Tel Aviv University, Israel
}

Kauli, R., and Laron, Z. (1974). Archives of Disease in Childhood, 49, 482. A vasopressin analogue in treatment of diabetes insipidus. Six children, 3 adolescents, and 3 adults with vasopressin-sensitive diabetes insipidus were treated with a vasopressin analogue, DDAVP (1-deamino-8-D-arginine vasopressin), at a daily dose ranging from 5 to $20 \mu \mathrm{g}$ administered twice a day intranasally. The period of follow-up of these patients has been from 3 months to 1 year.

DDAVP was effective in maintaining normal diuresis and normal urine concentration during both day and night. No local or vasopressor side effects were observed. Compared to other antidiuretic drugs, such as nasal pitressin powder, lysine-vasopressin nasal spray, or pitressin tannate injections, used previously by the patients, DDAVP proved to be superior in the control of the diabetes insipidus and in the subjective feeling of the patients.

It is concluded that DDAVP is the drug of choice in the treatment of vasopressinsensitive diabetes insipidus.

Good control of diabetes insipidus is especially important in children since, in addition to the interference with normal school attendance, social activities, and night rest, normal growth is disturbed by the imbalance in water and electrolyte metabolism. Up to now none of the drugs employed have proved satisfactory and some have caused troublesome side effects.

We report our experience with a new antidiuretic preparation, DDAVP (1-deamino-8-D-arginine vasopressin), a synthetic analogue of the natural human antidiuretic hormone. Its features are a lack of pressor activity and side effects, together with a prolonged antidiuretic action.

\section{Subjects and methods}

Twelve patients ( 7 females and 5 males) with diabetes insipidus were included in this study. 9 were children or adolescents ( 5 years 9 months to 18 years) and 3 were adults. 2 of the adult patients (aged $22 \frac{1}{2}$ and 24 years) have been under our care since childhood, while the third, a 34-year-old patient with a pituitary tumour, was under the care of the Department of Neurosurgery.

The pertinent clinical data are summarized in Table $\mathbf{I}$.

Received 13 November 1973.
All patients had been proven to be vasopressin-sensitive and previously had been treated with nasal pitressin powder (PP) (Lilly), lysine-8-vasopressin nasal spray (LVP) (Sandoz), or intramuscular injections of pitressin tannate in oil (PTO), with varying success.

Two of the patients treated with LVP nasal spray required the drug at least three to four times a day and had to get up at night to urinate. Because of its short effectiveness, LVP was abandoned by most patients.

Six patients had been treated with PP intranasally. They required the drug two to four times a day, and all complained of vasopressor effects and of local irritation of the hasal mucosa. 1 patient (Case 5) switched to therapy with injections of PTO for various periods of time until the sore nasal mucosa had recovered, then changed back to the nasal powder because the injections were too painful to endure for long. Another patient (Case 4) reduced the dosage of the powder and supplemented it with carbamazepine (Tegretol), preferring the less satisfactory control of the diabetes insipidus to the troublesome side effects of the powder when taken at a fully effective dosage.

Two of the younger patients (Cases 7 and 9) could be managed only with PTO injections, both requiring an injection every other day. Even so, satisfactory control was not achieved and both suffered from pronounced nocturnal enuresis. The older of the 2 (Case 9) was unable to attend school properly because of her intractable polyuria and polydipsia. 
TABLE I

Pertinent clinical data of subjects studied with diabetes insipidus

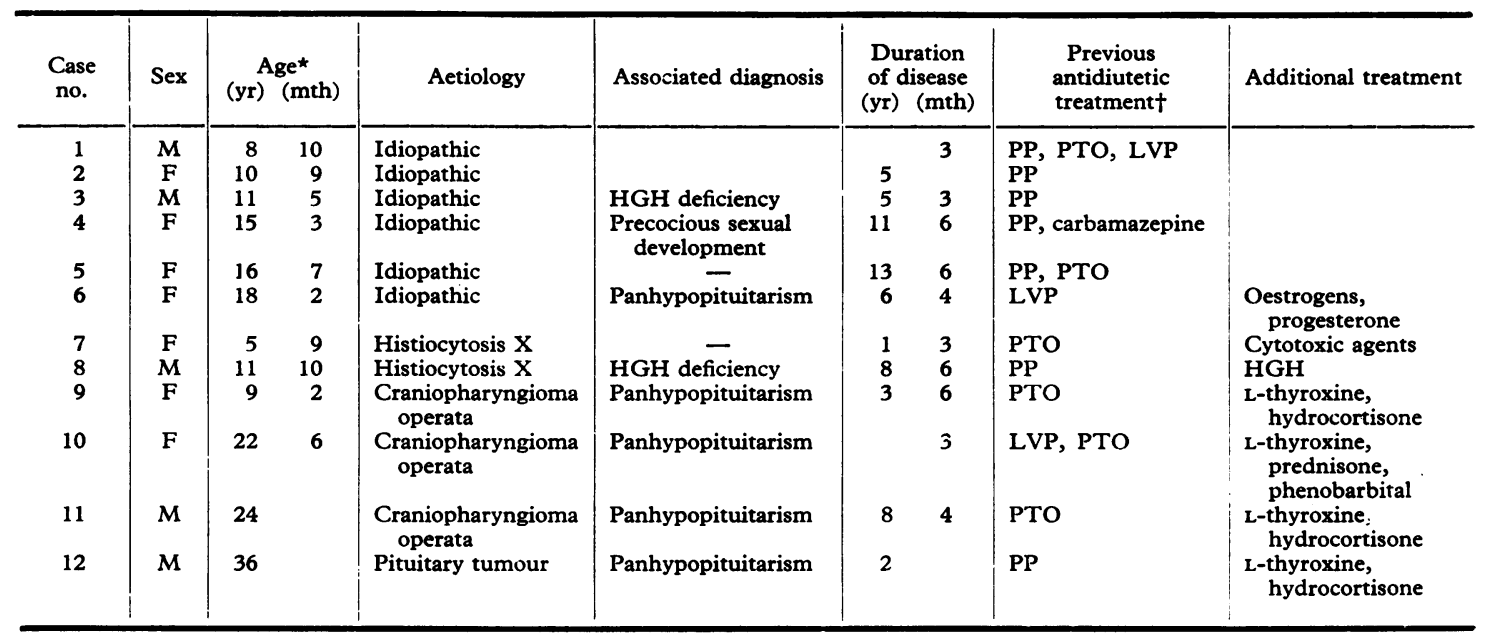

^Age at start of DDAVP therapy.

†PP, pitressin powder (Lilly); PTO, pitressin tannate in oil; LVP, lysine vasopressin spray (Sandoz).

Two of the adult patients (Cases 10 and 11) could not stand the vasopressor and local side effects of the intranasal spray and therefore switched to therapy with PTO injections.

One patient (Case 1) presented a particularly difficult therapeutic problem. Initially, the diabetes insipidus responded well to each of the above preparations, but in each case there was a rapid decrease in effectiveness (within several days to several weeks), and finally a total lack of response. Trials with various combinations of the vasopressin preparations as well as with chlorothiazide all failed.

All the 12 patients in this study were eventually placed on DDAVP therapy, but because of the limitation in the supply of the drug at the beginning, the most difficult patients were the first to be started on it.

Data on the 24-hour urine volume and urine specific gravity were recorded for all patients both during the previous antidiuretic treatment and during treatment with DDAVP. Urine osmolality was also determined in most patients during both periods. In 4 patients all antidiuretic therapy was stopped for 24 to 48 hours before DDAVP therapy was started, so that data could also be obtained for the nontreatment period.

All patients were given DDAVP intranasally in a solution containing $100 \mu \mathrm{g} / \mathrm{ml}$, administered by means of a graded nasal tube. There were no technical difficulties in teaching the patients to perform the insufflation by themselves, and only with the youngest patient (Case 7) did an older member of the family have to administer the drug.

The initial dose was $5 \mu \mathrm{g}(0.05 \mathrm{ml})$ administered twice daily. The smallest effective dose was determined for each patient by gradually increasing the dosage until normalization was achieved, as measured by urine volume and concentration and daily fluid intake.

In evaluating the effectiveness of DDAVP, the patient's general well-being, school performance, and social activities were included.

\section{Results}

Table II presents the data recorded on urine volume, osmolality, and specific gravity during the different types of treatment, including the periods of complete withdrawal in the 4 patients noted above. In all patients there was a clear improvement with DDAVP therapy, with a reduction in urine volume and an increased ability to concentrate the urine, as measured by the specific gravity and osmolality. The contrast is particularly obvious with the data for the 4 patients who underwent a period of withdrawal, comparing the periods of nontreatment with that of DDAVP therapy. The superiority of DDAVP over the vasopressive therapies previously used is clear.

For most patients the smallest effective dose proved to be $10 \mu \mathrm{g}(0 \cdot 1 \mathrm{ml})$ twice daily, only Case 4 requiring double that dose. $U p$ to now, with the period of follow-up ranging from 3 months to a year, there has been no evidence of resistance developing to DDAVP.

The drug is taken in the morning and in the evening before retiring. On this regimen, the polyuria and polydipsia were satisfactorily 
TABLE II

Effect of DDAVP on urine volume and concentration compared with that using other antidiuretic agents

\begin{tabular}{|c|c|c|c|c|c|c|c|c|c|c|}
\hline \multirow[b]{2}{*}{$\begin{array}{c}\text { Case } \\
\text { no. }\end{array}$} & \multirow{2}{*}{$\begin{array}{l}\text { Previous } \\
\text { antidiuretic } \\
\text { therapy }\end{array}$} & \multicolumn{3}{|c|}{ Urine volume $(1 . / 24 \mathrm{hr})$} & \multicolumn{3}{|c|}{ Urine specific gravity† } & \multicolumn{3}{|c|}{ Urine osmolality ( $\mathrm{mOsm} / \mathrm{kg} \mathrm{H}_{2} \mathrm{O}$ ) } \\
\hline & & $\begin{array}{l}\text { On } \\
\text { previous } \\
\text { therapy }\end{array}$ & $\begin{array}{l}\text { Without } \\
\text { any } \\
\text { therapy }\end{array}$ & $\begin{array}{l}\text { On } \\
\text { DDAVP }\end{array}$ & $\begin{array}{l}\text { On } \\
\text { previous } \\
\text { therapy }\end{array}$ & $\begin{array}{l}\text { Without } \\
\text { any } \\
\text { therapy }\end{array}$ & $\begin{array}{c}\text { On } \\
\text { DDAVP }\end{array}$ & $\begin{array}{l}\text { On } \\
\text { previous } \\
\text { therapy }\end{array}$ & $\begin{array}{l}\text { Without } \\
\text { any } \\
\text { therapy }\end{array}$ & $\stackrel{\text { On }}{\text { DDAVP }}$ \\
\hline 1 & $\begin{array}{l}\text { PP, PTO, LVP, } \\
\text { thiazides }\end{array}$ & $3-4$ & $5-6$ & $1 \cdot 5$ & 1000 & 1000 & 1025 & 100 & 57 & 920 \\
\hline 2 & PP & $2 \cdot 5$ & $4-5$ & 1 & 1000 & 1000 & 1019 & 67 & 70 & 730 \\
\hline 3 & PP & $2-3$ & 6 & $1 \cdot 5$ & 1003 & 1000 & 1023 & 188 & 108 & 1005 \\
\hline 4 & $\begin{array}{l}\mathrm{PP}+ \\
\quad \text { carbamazepine }\end{array}$ & $2-3 \cdot 5$ & 一 & $1 \cdot 5$ & 1005 & - & 1018 & 868 & 一 & - \\
\hline 5 & PP, PTO & 3 & - & $1 \cdot 5$ & 1011 & - & 1020 & - & - & 740 \\
\hline 6 & LVP & $2 \cdot 5$ & - & $1 \cdot 2$ & 1005 & - & 1016 & 93 & - & 588 \\
\hline 7 & PTO & 4 & - & 1 & 1000 & - & 1012 & 59 & - & 564 \\
\hline 8 & PP & $\begin{array}{c}\text { Enuresis } \\
2 \cdot 8\end{array}$ & 6 & $\begin{array}{l}\text { No enuresis } \\
1 \cdot 2\end{array}$ & 1000 & 1000 & 1020 & 81 & 61 & 675 \\
\hline 9 & PTO & $\begin{array}{c}3 \\
\text { Enuresis }\end{array}$ & - & $\begin{array}{c}1 \\
\text { No enuresis }\end{array}$ & 1008 & - & 1020 & - & - & - \\
\hline 10 & LVP, PTO & 4 & - & $1-1 \cdot 5$ & 1005 & 一 & 1017 & - & - & - \\
\hline 11 & PTO & $2-3$ & 一 & 1 & 1010 & - & 1029 & 197 & 一 & 575 \\
\hline 12 & PP & $2-2 \cdot 5$ & - & $1 \cdot 5$ & 1007 & - & 1023 & 690 & - & 760 \\
\hline
\end{tabular}

^Previous therapy was stopped for 24 to $48 \mathrm{hr}$ before starting DDAVP.

Urine specific gravity and osmolality measured at random.

controlled for periods of 10 to 12 hours, granting the patients a feeling of security and freedom during the day. The antidiuretic effect of DDAVP was most pronounced during the morning hours, assuring convenience in school and at work, and lessening in the late afternoon. The evening dose permitted all patients an uninterrupted night's sleep without bed wetting. While all patients had previously carried an antidiuretic drug with them when leaving home, this proved unnecessary on DDAVP therapy.

Parents and teachers, as well as the patients themselves, reported improvement in overall achievement, at school in the younger ones and at work in the older ones. 2 of the children took part in day-long class excursions, something they would never have dared to do before. There was also a general sense of a lowering of tension in family relationships.

All patients remarked on the gratifying lack of any discomfort associated with DDAVP. No side effects, either general or local, have been noted.

The necessity of keeping the drug at a low temperature was shown, since 2 patients reported a reduced effect when it was not refrigerated; the average room temperature in this country is high (26-30 ${ }^{\circ} \mathrm{C}$ in summer).

\section{Discussion}

Vasopressin preparations generally available have three major disadvantages, inconvenience of administration, vasopressor and local side effects, and short duration of effectiveness. Refractoriness to therapy and allergic reactions also develop in some patients (Mimica, Wegienka, and Forsham, 1968; Bronstein, DeFelice, and Long, 1969; Laron, 1969; Lawrence, Hsu, and Lichtenstein, 1972).

Other drugs with antidiuretic properties, such as thiazides (Lant and Wilson, 1971), carbamazepine (Tegretol) (Delzant, Sebaoun, and Krivitzky, 1971; Stoll, Largier, and Tönz, 1972), clofibrate (De Gennes et al., 1970), and chlorpropamide (Kumar, Sutow, and Cole, 1969; Ehrlich and Kooh, 1970; Reimold, 1970), have been tested with varying results. Largely unsatisfactory results as well as unpleasant side effects have been reported (Pinto and Stoppoloni, 1970).

Our study confirms the findings reported by others (Vavrá et al., 1968; Andersson and Arner, 1971, 1972; Aronson et al., 1973; Edwards et al., 1973) that DDAVP lacks the disadvantages of the older vasopressin preparations: it is convenient to administer, there are no undesirable vasopressor or local side effects, and the duration of its effect is long enough (10 to 12 hours) to permit the patient to undertake normal activities. These qualities of DDAVP are ascribed to the differences in its chemical structure compared to natural human vasopressin, i.e. the deamination of hemicystine in position 1 and the presence of a $D$-arginine in position 8 . It is believed that these structural changes increase the antidiuretic over the vasopressor effect and are responsible for the prolonged antidiuretic action, partly by delaying enzymatic 
degradation in the peripheral tissues (Aronson et al., 1973).

Since submitting this paper, Nash (1973) has reported the case of a child of 10 years successfully treated with DDAVP.

We conclude that DDAVP is the drug of choice, giving satisfactory control of the symptoms of diabetes insipidus with practically no discomfort, and making possible a normal life.

DDAVP was kindly supplied by Dr. Jan Mulder of Ferring Ab, Malmö, Sweden. Measurements of urinary osmolalities were performed by Mrs. Batia Hengal and Mrs. Rivka Pansky of the Renal Laboratory, Beilinson Medical Center.

\section{REFERENCES}

Andersson, K. E., and Arner, B. (1971). Treatment of diabetes insipidus. British Medical fournal, 3, 111.

Andersson, K. E., and Arner, B. (1972). Effect of DDAVP, a synthetic analogue of vasopressin, in patients with cranial diabetes insipidus. Acta Medica Scandinavica, 192, 21.

Aronson, A. S., Andersson, K. E., Bergstrand, C. G., and Mulder, J. L. (1973). Treatment of diabetes insipidus in children with DDAVP, a synthetic analogue of vasopressin. Acta Paediatrica Scandinavica, 62, 133.

Bronstein, S. B., DeFelice, E. A., and Long, D. (1969). Evaluation of lysine-8 vasopressin nasal spray in 641 patients with diabetes insipidus. Fournal of the American Medical Association, 208, 1481.

De Gennes, J. L., Bertrand, C., Bigorie, B., and Truffert, J. (1970). Études preliminaires de l'action antidiurétique du clofibrate (ou atromid S) dans le diabète insipide pitresso-sensible. Annales d'Endocrinologie, 31, 300.

Delzant, G., Sebaoun, J., and Krivitzky, A. (1971). Utilisation du carbamoyl-dibenzo-azepine (Tegretol) dans la thérapeutique du diabète insipide. Annales d'Endocrinologie, 32, 540.

Edwards, C. R. W., Kitau, M. J., Chard, T., and Besser, G. M. (1973). Vasopressin analogue DDAVP in diabetes insipidus: clinical and laboratory studies. British Medical fournal, 3, 375.
Ehrlich, R. M., and Kooh, S. W. (1970). The use of chlorpropamide in diabetes insipidus in children. Pediatrics, 45, 236.

Kumar, R. S., Sutow, W. W., and Cole, V. W. (1969). Chlorpropamide in diabetes insipidus. Lancet, 1, 577.

Lant, A. F., and Wilson, G. M. (1971). Long-term therapy of diabetes insipidus with oral benzothiadiazine and phthalimidine diuretics. Clinical Science, 40, 497.

Laron, Z. (1969). The hypothalamus and the pituitary gland. In Pediatric Endocrinology, p. 82. Ed. by D. Hubble. Blackwell Scientific Publications, Oxford and Edinburgh.

Lawrence, G. D., Hsu, T. H., and Lichtenstein, L. M. (1972). Diabetes insipidus with hypersensitivity to pitressin. An immunological study. Fohns Hopkins Medical fournal, 131, 172.

Mimica, N., Wegienka, L. C., and Forsham, P. H. (1968). Lypressin nasal spray. Usefulness in patients who manifest allergies to other antidiuretic hormone preparations. Fournal of the American Medical Association, 203, 802.

Nash, H. (1973). Treatment with new synthetic analogue of vasopressin in diabetes insipidus. Archives of Disease in Childhood, 48, 979.

Pinto, L., and Stoppoloni, G. (1970). Diabetes insipidus, chloṛpropamide and hypoglycemia. Pediatrics, 46, 822.

Reimold, E. W. (1970). Chlorpropamide in the treatment of diabetes insipidus in children. American fournal of Diseases of Children, 120, 103.

Stoll, E., Largier, H., and Tönz, O. (1972). Behandlung eines kindliche Diabetes insipidus centralis mit Chlorpropamid (Diabenese) und Carbamazepin (Tegretol). Schweizerische Medizinische Wochenschrift, 102, 10.

Vavrá, I., Machová, A., Holeček, V., Cort, J. H., Zaoral, M., and Sorm, F. (1968). Effect of a synthetic analogue of vasopressin in animals and in patients with diabetes insipidus. Lancet, 1, 948.

Correspondence to Professor Z. Laron, Institute of Paediatric and Adolescent Endocrinology, Beilinson Medical Center, Petach Tikva, Israel.

\section{Addendum}

Since the submission of this paper we have successfully treated with DDAVP 3 more patients with diabetes insipidus, aged 7,15 , and 18 years. 